\title{
The Pyrolysis of Glycerol Using Microwave for the Production of Hydrogen
}

\author{
Lailatul Qadariyah ${ }^{1}$, Mahfud $^{1}$, Pantjawarni Prihatini ${ }^{1}$, Sofyan Hadi ${ }^{1} \&$ Yuni Kurniati $^{1}$ \\ ${ }^{1}$ Department of Chemical Engineering, Sepuluh Nopember Institute of Technology, Indonesia \\ Correspondence: Lailatul Qadariyah, Department of Chemical Engineering, Sepuluh Nopember Institute of \\ Technology, Surabaya, 60111, Indonesia. E-mail: lailatul_2008@yahoo.com
}

Received: May 4, 2015

Accepted: June 5, 2015

Online Published: June 30, 2015

doi:10.5539/mas.v9n7p74

URL: http://dx.doi.org/10.5539/mas.v9n7p74

\begin{abstract}
The purpose of this research was to study pyrolysis of glycerol to produce hydrogen using microwave. The use of microwave aimed to produce high temperatures, because pyrolysis require high temperature. The effect of kind of catalyst and microwave power were studied. The catalyst was activated carbon and Ni/HZSM-5.The catalyst of activated carbon was ready to use, whereas Ni/HZSM- 5 catalyst was obtained by ion exchange from Na-ZSM-5 with $\mathrm{NH}_{4} \mathrm{Cl}$ and then HZSM-5 was impregnated with metal solution of $\mathrm{Ni}\left(\mathrm{NO}_{3}\right)_{2} .6 \mathrm{H}_{2} \mathrm{O}$. Experiments were conducted by mixing catalyst in the reactor together with glycerol solution of $10 \%$ (weight percent) as much as $100 \mathrm{ml}$. Reactor was made from pyrex and mounted on microwave equipped with a thermocouple. And then, reactor was heated on power of 400-700 Watt during thirty minutes. The reaction produced gases and liquid to be analyzed by chromatography gas. The conclusion stated that microwave could pyrolysis glycerol into hydrogen. By product of this reaction were methanol, allyl alcohol, acrolein and unidentified products. The difference of catalyst produced different product as well. The pyrolysis of glycerol using activated carbon produced conversion of $60 \%$, while using catalysts Ni/HZSM- 5 obtained conversion of $87 \%$. The reaction produced hydrogen gases was relatively small for both of catalysts that is minimum of $0,59 \%$ and maximum of $0,88 \%$.
\end{abstract}

Keywords: pyrolysis, glycerol, hydrogen, microwave

\section{Introduction}

At this time, the energy crisis is a hot issue that is common throughout the world and also in Indonesia. Fossil fuels are the main source of the world's energy needs at the moment is getting scarce availability. This is due to the depletion of world oil reserves. In Indonesia, the number of petroleum reserves declined from 5.1 billion barrels in 2000 to 3.7 billion barrels in 2008. In addition, the the need for fossil fuels increases as population growth and development in all fields that cause the source diminishing fossil energy.

Besides, the problem of energy crisis occurred, the use of fossil fuels currently has negative effects to the environment that result in greenhouse gas emissions are a main cause of global warming. Fossil energy source that is often used is diesel oil for industrial and transportation sectors. In an effort to meet the demand for diesel, biodiesel in Indonesia has been developed which is an alternative to diesel fuel.Biodiesel is a mixture of diesel fuel and methyl ester in which the methyl ester obtained by transesterification of vegetable oils with methanol using $\mathrm{NaOH}$ as catalyst and produce byproducts such as glycerol.Glycerol is a by-product resulting from the production of biodiesel is about $10 \%$ by weight of biodiesel. With the increasing production of biodiesel, the production of glycerol has increased as well, while the needs of glycerol is very limited. It will decrease the economic side and can be a waste of biodiesel plant and also increase production costs (Daskalaki, 2008).

While, biodiesel is widely used in the food industry, cosmetics or pharmaceuticals, but the industry needs to glycerol is still in limited quantities. Beside that, glycerol can be degraded into other compounds that have economic value as a fuel that is hydrogen (Byrd et al., 2008) or methanol (Tsukuda et al., 2007) and other chemical products that have added value such as acrolein (Wang et al., 2009), propane (Murata et al., 2008), and lactic acid (Yuksel et al., 2009) to degrade glycerol. The degradation of glycerol can be done in various processes such as pyrolysis (Vallyapan et al., 2008), steam reforming (Adhikari et al., 2007), and catalytic hydrogenation (Murata et al., 2008). 
One of a potential alternative energy source in future is hydrogen. Hydrogen is a fuel that is environmentally friendly because it does not produce pollutants or greenhouse gases such as $\mathrm{NOx}, \mathrm{CO}$ and $\mathrm{CO}_{2}$ when burned (Iriondo, 2009; Daskalaski, 2009). Hydrogen needs in various industries increases, particularly with the development of the industry of fuel cell. It requires $\mathrm{H}_{2}$ as fuel (Adhikari, 2008). Some efforts to produce hydrogen has been conducted, but so far about $95 \%$ of $\mathrm{H}_{2}$ is produced from fossil fuels via pyrolysis or steam reforming (Adhikari, 2008; Iriondo, 2009) and only about 5\% is produced through renewable sources. One technology that is used is through the process of electrolysis of water (Park et al., 2008). Both types of these processes are still an intermediate technology, because it requires energy to produce hydrogen (Nianjun Luo, 2009).

Hydrogen can be produced from glycerol in various ways, namely steam reforming, pyrolysis, supercritical water reforming that are usually carried out with conventional heating and requires high temperatures. Based on this, it is necessary to develop innovative methods to produce high temperature by using microwaves. Microwave heating is volumetric, selective, and superheating in the liquid and produces a hot spot on the solids. This nature is what distinguishes microwave heating with conventional heating. Microwave heating produces benefits, such as faster reaction and higher product yields than conventional heating. Fidalgo et al. (2008) has made reforming of methane to produce syngas with a microwave and conventional heating at a temperature of $600-800^{\circ} \mathrm{C}$ using activated carbon catalyst. This study suggests that microwave heating produces a faster reaction than conventional heating.

The only research related to the degradation of glycerol using microwave heating is done by Fernandez et al. (2009) that the pyrolysis of glycerol to produce hydrogen using activated carbon. Activated carbon is used in microwave heating to absorb a micro wave and also as a catalyst. The reaction is conducted at a temperature of 400 to $900^{\circ} \mathrm{C}$ at atmospheric pressure. Besides the use of microwave as a heating source, the reaction is also using conventional heating as the study of microwave heating. With microwave heating, syngas production increases even at low temperatures. Based on the description above, this study focuses on using microwave pyrolysis of glycerol to produce hydrogen using a catalyst. Pyrolysis of glycerol into hydrogen gas also requires a catalyst that is used in this study is also a wide variety of catalysts, namely activated carbon and Ni / HZSM-5 for this reaction. Various influential variables such as power and type of catalyst studied in this research.

\section{Method}

The materials used in this study was $87 \%$ glycerol $\left(\mathrm{C}_{3} \mathrm{H}_{8} \mathrm{O}\right)$, water $\left(\mathrm{H}_{2} \mathrm{O}\right)$, Ammonium chloride $\left(\mathrm{NH}_{4} \mathrm{Cl}\right)$, Ni $\left(\mathrm{NO}_{3}\right)_{2} \cdot 6 \mathrm{H}_{2} \mathrm{O}$, sulfuric acid $\left(\mathrm{H}_{2} \mathrm{SO}_{4}\right)$, hydrochloric acid $(\mathrm{HCl})$, Phenol Red, Sodium hydroxide $(\mathrm{NaOH}), \mathrm{SiO}$, and ethylene glycol from Merck. While $\mathrm{N}_{2}$ from P.T. Tri Gases, $\mathrm{H}_{2}$ Gases from P.T. Emi and catalyst in Surabaya, and Na-ZSM-5 from zeolist internationally in Japan.

Experiments were carried out in two stages: the preparation of catalysts and catalytic reactions. Preparation was done to change the catalyst Na-ZSM-5 to Ni-HZSM-5 by ion exchange. Ion exchange was done by adding ZSM-5 with $2 \mathrm{M}$ ammonium chloride solution three times with a ratio of ZSM-5 and ammonium chloride solution of 1:10. HZSM-5 formed was filtered, washed, and dried at $110^{\circ} \mathrm{C}$ for 6 hours followed by calcination at $500^{\circ} \mathrm{C}$ for 5 hours.

HZSM- 5 formed impregnated with a solution containing an active metal, $\mathrm{Ni}\left(\mathrm{NO}_{3}\right)_{2} \cdot 6 \mathrm{H}_{2} \mathrm{O}$ by slowly adding a solution of metal into HZSM-5 at ambient temperature. The solids were dried at a temperature of $110^{\circ} \mathrm{C}$ for 14 hours and calcined with flowing $\mathrm{N}_{2}$ at $550^{\circ} \mathrm{C}$ for 5 hours (Romero, 1997). After impregnation, the formed $\mathrm{NiO} / \mathrm{HZSM}-5$ is reduced by hydrogen at a temperature of $450^{\circ} \mathrm{C}$ for 3 hours to obtain Ni/HZSM- 5 .

After Ni/HZSM-5 catalyst was obtained, then catalyst was inserted into the reactor together with $10 \%$ glycerol solution of $100 \mathrm{ml}$ made of pyrex, and a reactor was put in microwave equipped with a thermocouple. Then the reactor was heated at power of 400 to 700 watts for 30 minutes. The formed products were gas and liquid and analyzed by gas chromatography. Catalysts used were Ni-HZSM-5 and activated carbon. The apparatus was schematically shown in Figure 1, whereas number 1 show microwave, 2 is reactor, and 3 is product container.

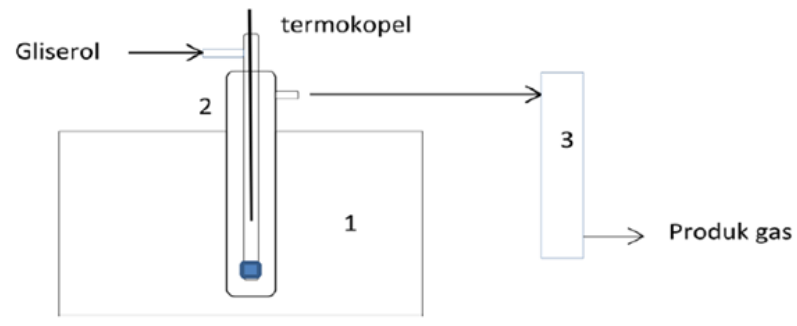

Figure 1. Experimental Apparatus of pyrolysis of Glycerol 


\section{Results and Discussion}

Pyrolysis of glycerol was performed using microwave at power of 400-700 Watt, reaction time of 30 minutes using activated carbon and Ni/HZSM-5 catalyst. Pyrolysis of glycerol produces liquid and gas. Liquid products are shown in Figure 2-3 and Gases Products are shown in Figure 4. Figure 2-4 is chromatogram of GC analysys where the abscissa shows retention time, and the ordinate shows intensity. The formed liquid products is methanol, allyl alcohol, and acrolein. Methanol, allyl alcohol and acrolein respectively indicated by retention time 2.196; 2.896, and 5.965. Besides, many other products are formed can't be identified which are shown in Figure 2-3 with the number of peaks. The identification was done by comparing chromatograms of products with chromatograms of standard solutions. In addition, Figures 2-3 also compare the products with various catalysts. With activated carbon catalyst produced products are methanol, allyl alcohol and acrolein, whereas Ni/HZSM-5 catalyst produces methanol and other products that can not be identified.

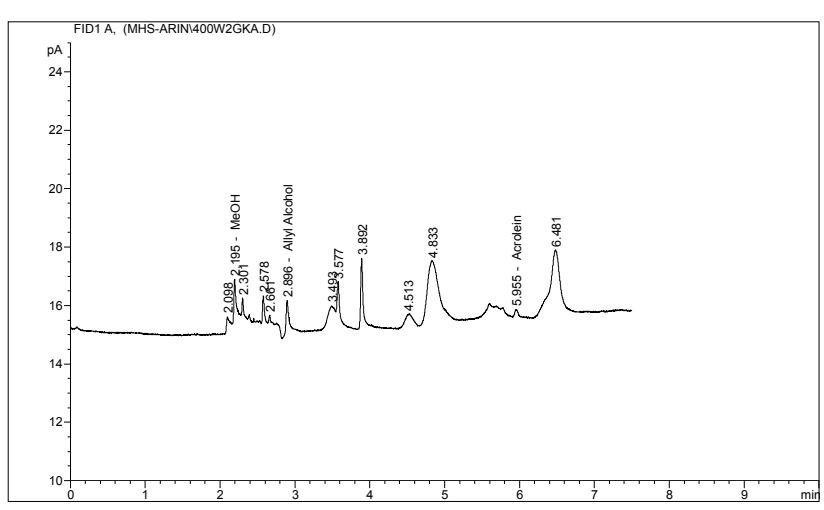

Figure 2. Chromatogram of Liquid Products at power of $400 \mathrm{~W}$ Using Activated Carbon Catalyst

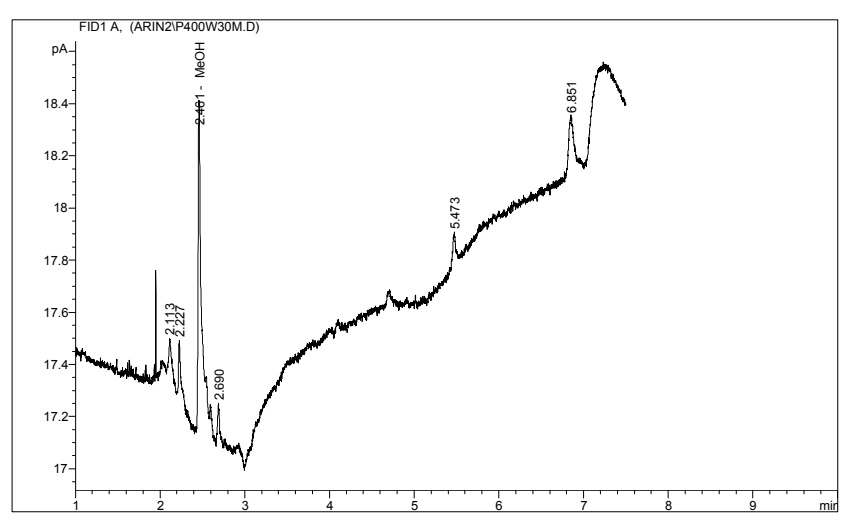

Figure 3. Chromatogram of Liquid Products at power of $400 \mathrm{~W}$ Using Ni/HZSM-5

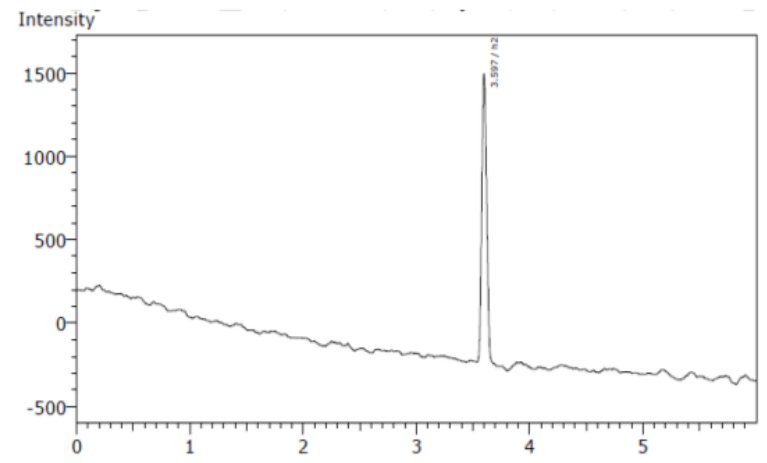

Figure 4. Chromatogram of Gas Products at power of $400 \mathrm{~W}$ Using Activated Carbon Catalyst

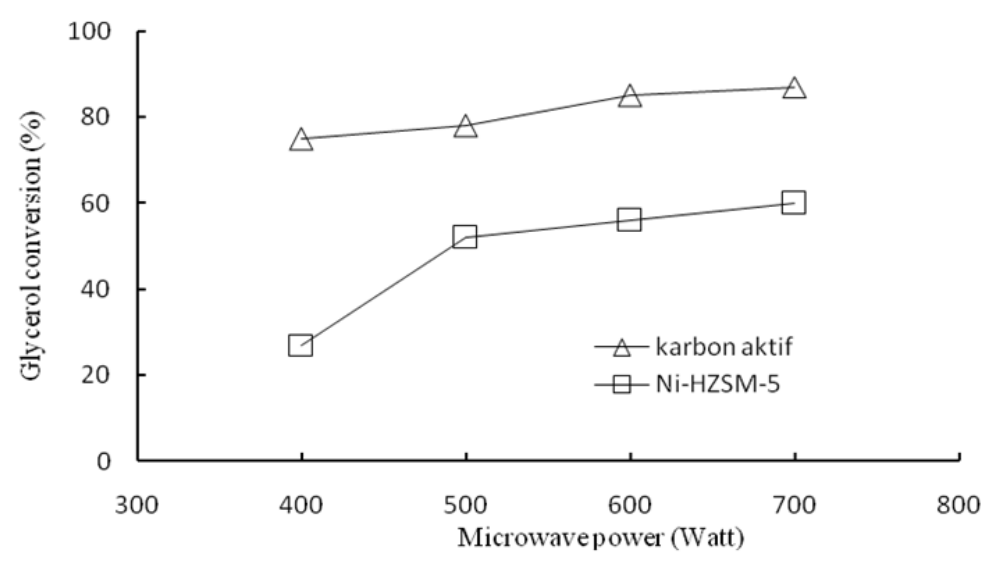

Figure 5. Effect of Microwave Power to Conversion of Glycerol 
Figure 4 shows that the gas product is hydrogen. It is indicated by retention time 3.597 . Figure 5 shows that the effect of power on the conversion of glycerol. Higher power gives higher reaction temperatures. Gabriel et al. (1998) stated that the increase of temperature causes the relaxation time of molecular decreases. Decrease of relaxation time of molecular indicates that the movement of inter-molecules is larger so that collisions are also getting bigger and causing converting greater glycerol. This is also seen in the experimental data that the greater power generate greater temperatures. Figure 5 also shows that the activated carbon catalysts result in greater conversion than Ni-HZSM-5 catalyst, since the activated carbon absorbs the micro waves so that it makes temperature is also higher than Ni-HZSM-5 catalyst

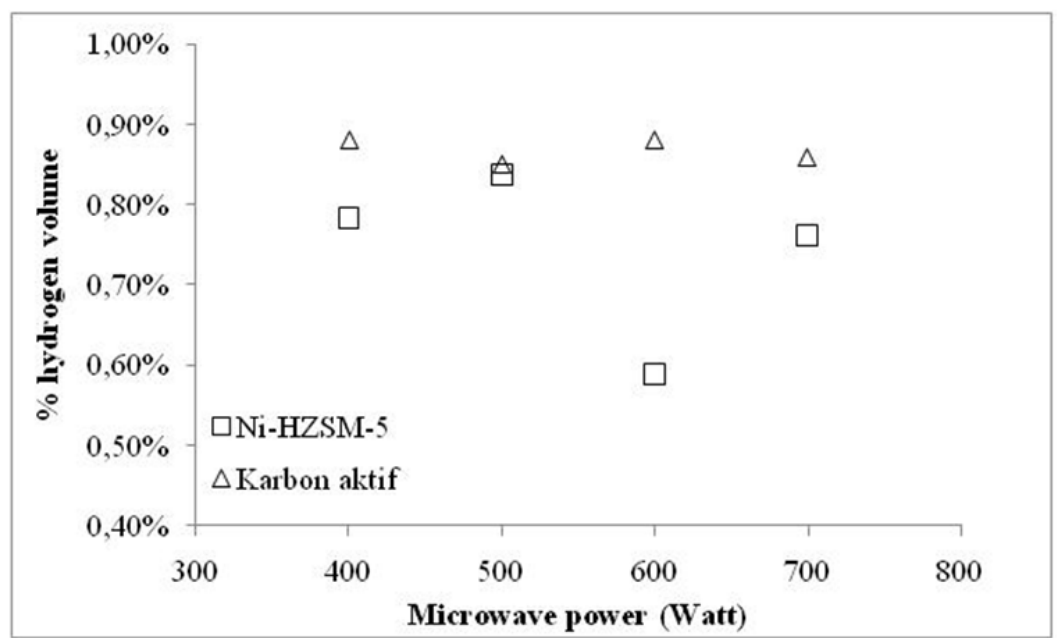

Figure 6. Effect of Microwave Power to \% Volume of Hydrogen

Figure 6 shows that the activated carbon produces gas more than Ni/HZSM- 5 catalyst, since the activated carbon absorbs the microwaves compared to Ni/HZSM-5 catalyst. It is also proven when there is a spark on activated carbon in experiments which shows that section has a higher temperature than the ambient temperature, and it is called a hot spot.

Beside of product of hydrogen gas, there is also a liquid product that are methanol, allyl alcohol and acrolein are shown in Figure 7. for both of catalyst. Figure 7. shows that the activated carbon catalyst produces methanol, allyl alcohol, and acrolein, although in Figure 7. do not appear to any product acrolein, but the chromatogram of GC analysis in Figure 2, shows that there is a product of acrolein but very small. This is due to the volatility of acrolein, so acrolein can move into gas product.

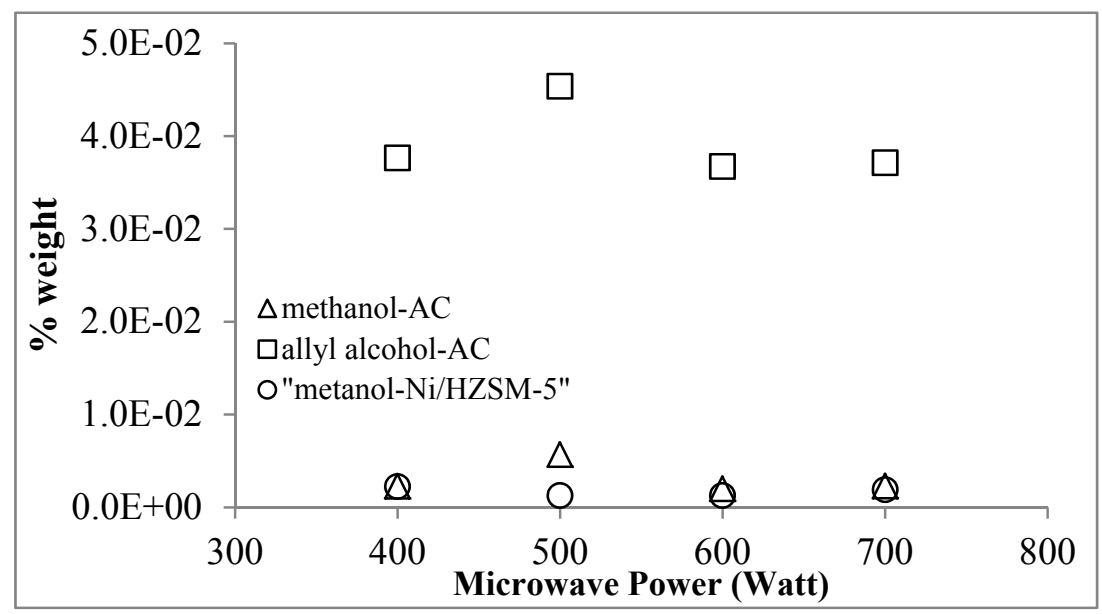

Figure 7. Effect of Microwave Power to \%wt of Liquid Products

Beside that, Figure 7 also shows that the variation of the product with the various catalyst. Activated carbon 
catalyst produces methanol, allyl alcohol, and acrolein, while Ni-HZSM-5 catalyst produces methanol.

\section{Conclusion}

The microwave can be used to pyrolysis of glycerol into hydrogen. In addition to products of hydrogen gas, there are also a liquid product such as of methanol, allyl alcohol, acrolein, and some products that can not be identified for both of catalyst. The use of different catalysts produces different products. Activated carbon catalyst produce more hydrogen than Ni/HZSM-5 catalyst.

\section{Acknowledgments}

This research is supported by Direktorat Jendral Pendidikan Tinggi, Kementrian Pendidikan Nasional through Hibah Penelitian Laboratorium 2014

\section{References}

Adhikari, S., Fernando, S., \& Haryanto, A. (2007). Production of Hydrogen By Steam Reforming of Glycerin Over Alumina-Supported Metal Catalysts. Catalysis Today, 12, 355-364. http://dx.doi.org/10.1016/j.cattod.2006.09.038

Buhler, W., Dinjus, E., Ederer, H. J., Kruse, A., \& Mas, C. (2002). Ionic Reactions and Pyrolysis of Glycerol As Competing Reaction Pathways In Near- and Supercritical Water. Journal of Supercritical Fluids, 22, 37-53. http://dx.doi.org/10.1016/S0896-8446(01)00105-X

Byrd, A. J., Pant, K. K., \& Gupta, R. B. (2008). Hydrogen Production From Glycerol by Reforming in Supercritical Water Over Ru/Al2O3 Catalyst. Fuel, 87, 2956-2960. http://dx.doi.org/10.1016/j.fuel.2008.04.024

Daskalaki, Vasileia, M., Kondarides, \& Dimitris, I. (2008). Efficient production of hydrogen by photo induced reforming of glycerol at ambient conditions. Journal of Catalysis, 144, 75-80.

Fernandez, Y., Arenillas, A., Diez, M. A., Pis, J. J., \& Menendez, J. A. (2009). Pyrolysis of Glycerol Over Activated Carbons For Syngas Production. Journal of analytical and Applied Pyrolysis, 84, 145-150. http://dx.doi.org/10.1016/j.jaap.2009.01.004

Fidalgo, B., Dominguez, A., Pis, J. J., \& Menendez, J. A. (2008). Microwave-Assisted Dry Reforming of Methane. International Journal of Hydrogen Energy, 33, 4337-4344. http://dx.doi.org/10.1016/j.ijhydene.2008.05.056

Iriondo, A., Barrio, V. L., Cambra, J. F., Arias, P. L., Güemez, M. B., Navarro, R. M., Sanchez-Sanchez, M. C., \& Fierro, J. L. G. (2009). Influence of $\mathrm{La}_{2} \mathrm{O}_{3}$ modified support and $\mathrm{Ni}$ and $\mathrm{Pt}$ active phases on glycerol steam reforming to produce hydrogen. Journal of Catalysis Communications, 1275-1278. http://dx.doi.org/10.1016/j.catcom.2009.02.004

Menéndez, J. A., Arenillas, A., Fidalgo, B., Fernández, Y., Zubizarreta, L., Calvo, E. G., \& Bermúdez, J. M. (2010). Microwave Heating Processes Involving Carbon Materials. Fuel Processing Technology, 91, 1-8. http://dx.doi.org/10.1016/j.fuproc.2009.08.021

Murata, K., Takahara, I., \& Inaba, M. (2008). Propane Formation By Aqueous-Phase Reforming of Glycerol Over Pt/HZSM-5 Catalysts. Reaction Kinetics and Catalysis Letters, 93, 59-66. http://dx.doi.org/10.1007/s11144-008-5190-0

Nianjun, L., Zheng, J., Huahong, S., Fahai, C., Tiancun, X., \& Edwards, P. P. (2009). Photo-catalytic conversion of oxygenated hydrocarbons to hydrogen over heteroatom-doped $\mathrm{TiO} 2$ catalysts. Journal of Catalysi, 34, $125-129$.

Ott, L., Bicker, M., \& Vogel, H. (2006). Catalytic Dehydration of Glycerol In Sub- and Supercritical Water: A New Chemical Process For Acrolein Production. Green Chemistry, 8, 214-220. http://dx.doi.org/10.1039/B506285C

Park, H., Vecitis, C. D., Wonyong, Choi, Oleh, W., \& Hoffmann, M. R. (2008). Solar Powered Production of Molecular Hydrogen from Water. The Journal of Physical Chemistry C Letters, 112, $885-889$. http://dx.doi.org/10.1021/jp710723p

Tsukuda, E., Sato, S., Takahashi, R., \& Sodesawa, T. (2007). Production of acrolein from glycerol over silica-supported heteropoly acids. Catalysis Communications, 8, 1349-1353. http://dx.doi.org/10.1016/j.catcom.2006.12.006

Valliyapan, T., Bakhshi, N. N., \& Dalai, A. K. (2008). Pyrolysis of Glycerol For The Production of Hydrogen or 
Syngas. Bioresource Technology, 99, 4476-4483. http://dx.doi.org/10.1016/j.biortech.2007.08.069

Wang, F., Dubois, J. L., \& Ueda, W. (2009). Catalytic dehydration of Glycerol Over Vanadium Phosphate Oxides In The Presence of Molecular Oxygen. Journal of Catalysis, 268, 260-267. http://dx.doi.org/10.1016/j.jcat.2009.09.024

Yuksel, A., Koga, H., Sasaki, M., \& Goto, M. (2009). Electrolysis of Glycerol in Subcritical Water. Journal Renewable Sustainable Energy 1, 033112, 1-12. http://dx.doi.org/10.1063/1.3156006

\section{Copyrights}

Copyright for this article is retained by the author(s), with first publication rights granted to the journal.

This is an open-access article distributed under the terms and conditions of the Creative Commons Attribution license (http://creativecommons.org/licenses/by/3.0/). 